\title{
Degradation of chlorinated and brominated hydrocarbons by Methylomicrobium album BG8
}

Received: 17 June 1999 / Accepted: 3 September 1999

\begin{abstract}
The degradation kinetics of ten halogenated hydrocarbons by Methylomicrobium album BG8 expressing particulate methane monooxygenase (pMMO) and the inhibitory effects of these compounds on microbial growth and whole-cell pMMO activity were measured. When $M$. album BG8 was grown with methane, growth was completely inhibited by dichloromethane (DCM), bromoform (BF), chloroform (CF), vinyl chloride (VC), 1,1-dichloroethylene (1,1-DCE), and cis-dichloroethylene (cis-DCE). Trichloroethylene (TCE) partially inhibited growth on methane, while dibromomethane (DBM), trans-dichloroethylene (trans-DCE), and 1,1,1-trichloroethane (1,1,1-TCA) had no effect. If the cells were grown with methanol, DCM, BF, CF, and 1,1-DCE completely inhibited growth, while VC, trans-DCE, TCE, and 1,1,1-TCA partially inhibited growth. Both DBM and cis-DCE had no effect on growth with methanol. Whole-cell pMMO activity was also affected by these compounds, with all but 1,1,1-TCA, DCM, and DBM reducing activity by more than $25 \%$. DCM, DBM, VC, trans-DCE, cis-DCE, 1,1-DCE, and TCE were degraded and followed Michaelis-Menten kinetics. CF, BF, and 1,1,1-TCA were not measurably degraded. These results suggested that the products of DCM, TCE, VC, and 1,1-DCE inactivated multiple enzymatic processes, while trans-DCE oxidation products were also toxic but to a lesser extent. cis-DCE toxicity, however, appeared to be localized to pMMO. Finally, DBM and 1,1,1-TCA were not inhibitory, and CF and BF were themselves toxic to $M$. album BG8. Based on these results, the compounds could be separated into four general categories, namely (1) biodegradable with minimal inactivation, (2) biodegradable with substantial inactivation, (3) not biodegradable with minimal inactivation, and (4) not biodegradable but substantial inactivation of cell activity.
\end{abstract}

J.-I. Han · S. Lontoh · J. D. Semrau (凶)

Department of Civil and Environmental Engineering,

The University of Michigan, Ann Arbor, MI 48109-2125, USA

e-mail: jsemrau@engin.umich.edu,

Tel.: +1-734-7646487, Fax: +1-734-7632275
Key words Methanotrophs - Bioremediation . Halogenated hydrocarbons $\cdot$ Kinetics

Abbreviations $p M M O$ Particulate methane monooxygenase - $A M O$ Ammonia monooxygenase . $s M M O$ Soluble methane monooxygenase $\cdot D B M$ Dibromomethane $\cdot D C M$ Dichloromethane $\cdot B F$ Bromoform - $C F$ Chloroform - $V C$ Vinyl chloride . 1,1-DCE 1,1-Dichloroethylene · cis-DCE cis-Dichloroethylene $\cdot$ trans-DCE transDichloroethylene - TCE Trichloroethylene . 1,1,1-TCA 1,1,1-Trichloroethane

\section{Introduction}

Halogenated hydrocarbons are common pollutants in the United States and are found in aquifers, landfills, wastewaters, and waste disposal sites (Westrick et al. 1984; Semprini 1997). Once in the environment, these compounds have been shown to undergo a variety of anaerobic and aerobic biotransformations. Under anoxic conditions, biologically mediated dechlorination reactions have been found to be relatively slow and can result in the accumulation of harmful metabolites such as cis-dichloroethylene (cis-DCE) and the carcinogen vinyl chloride (VC) (Bouwer and McCarty 1983; Vogel and McCarty 1985; DiStefano et al. 1991). Under oxic conditions, however, many of these halogenated hydrocarbons can be cometabolically oxidized by bacteria expressing monoand dioxygenases when growing on methane, propane, phenol, ammonia, or toluene (Ensley 1991; Arp 1995; Wackett 1995).

Of these microorganisms, methanotrophs, gram-negative bacteria that utilize methane for both carbon and energy, have been extensively studied (Hanson and Hanson 1996). The enzyme responsible for the initial oxidation of methane, methane monooxygenase (MMO), can also oxidize aliphatic and aromatic hydrocarbons including priority pollutants such as trichloroethylene. Modeling and control of methanotrophic degradation of halogenated hy- 
drocarbons, although feasible, is complicated by the fact that multiple forms of the MMO exist. Some methanotrophs can synthesize a cytoplasm-associated MMO, or soluble methane monooxygenase (sMMO). This form of MMO has a relatively broad substrate range and has been extensively characterized (Fox et al. 1990; Cardy et al. 1991; Rosenzweig et al. 1993). Most known methanotrophs, however, can only express a membrane-bound, or particulate methane monooxygenase (pMMO). This form of MMO is found in all known methanotrophs, but its substrate range is narrower than that of sMMO, and its rate of trichloroethylene (TCE) degradation is approximately one order of magnitude less than that of sMMO (Lontoh and Semrau 1998).

Despite the low rates of chlorinated hydrocarbon degradation, pMMO-mediated oxidation of small halogenated hydrocarbons can be useful, particularly for in situ remediation, since most known methanotrophs can only express pMMO. In at least one field demonstration, it has been speculated that pMMO was expressed by natural methanotrophic populations after they had been stimulated through provision of methane and air (McCarty 1997). Based on the fact that most known methanotrophs can only express pMMO, and pMMO expression can apparently be increased in situ, we have examined (1) the oxidation of chlorinated and brominated one- and twocarbon compounds by Methylomicrobium album BG8 expressing pMMO, and (2) how these compounds affect methanotrophic activity. Correlation of the kinetics of degradation with assays of microbial growth and activity suggested that the compounds tested could be categorized into several groups, as has been seen for chlorinated methane, ethane, and ethylene cometabolism by the ammonia oxidizer Nitrosomonas europaea (Rasche et al. 1991), namely: (1) not biodegradable and little toxicity to M. album BG8, (2) biodegradable with little toxicity, and (3) biodegradable with substantial toxicity. Since methanotrophs and ammonia oxidizers have significant similarity, particularly substantial homology between sequences of the genes encoding ammonia monooxygenase and particulate methane monooxygenase (McTavish et al. 1993; Semrau et al. 1995), such a result is not surprising. Unlike the study of Rasche et al. (1991), however, we found two compounds that were best categorized in a fourth group, (4) not significantly biodegradable, but with substantial toxicity.

\section{Materials and methods}

\section{Culture conditions}

M. album BG8 was grown on nitrate mineral salt (NMS) medium (Whittenbury et al. 1970) at $30^{\circ} \mathrm{C}$ in batch flasks shaken at $250 \mathrm{rpm}$ in a methane/air atmosphere (1:2 ratio) at $1 \mathrm{~atm}$ of pressure. The culture medium was no more than $15 \%$ of the total flask volume to prevent mass transfer limitations of methane and oxygen from the head space to liquid medium. Since this strain can express only pMMO, $10 \mu \mathrm{M}$ was added aseptically as $\mathrm{Cu}\left(\mathrm{NO}_{3}\right)_{2} \cdot 2.5\left(\mathrm{H}_{2} \mathrm{O}\right)$ after autoclaving and was equilibrated for at least 2 days before the media were inoculated. This concentration of copper was added since previous work had shown that cells expressing pMMO de- graded TCE at high growth concentrations of copper (Lontoh and Semrau 1998).

Inhibition of cell growth by brominated and chlorinated hydrocarbons

The toxicity of halogenated hydrocarbons on methanotrophs expressing pMMO was examined by measuring the growth of $M$. album BG8 in the presence of these compounds. Cells were initially grown to the late exponential phase $\left(\mathrm{OD}_{600}\right.$ of 0.9$)$, and methane was removed by evacuating the growth flasks five times and allowing air to re-equilibrate after each evacuation. The cells were aseptically diluted 30 -fold into $3 \mathrm{ml}$ of NMS medium with $10 \mu \mathrm{M}$ copper and were transferred to $20-\mathrm{ml}$ serum vials for an initial $\mathrm{OD}_{600}$ of 0.023 . The vials were capped with Teflon-coated butylrubber stoppers (Wheaton) and crimp-sealed. Either $10 \mathrm{mM}$ methanol or $550 \mu \mathrm{M}$ methane (aqueous concentration) was then added as a growth substrate along with $100 \mu \mathrm{M}$ aqueous solution of one of the halogenated hydrocarbons. Duplicate vials were prepared for both the positive control (no halogenated hydrocarbon) and samples with a chlorinated or brominated hydrocarbon. The appropriate amount of substrate to add was calculated using the following dimensionless Henry's constants: methane, 27.02; VC, 1.262 (Morel and Hering 1991); bromoform (BF), 0.0281; dibromomethane (DBM), 0.0442; dichloromethane (DCM), 0.125; 1,1dichloroethylene (1,1-DCE), 1.355; trans-dichloroethylene (transDCE), 0.474; cis-dichloroethylene (cis-DCE), 0.197; 1,1,1-trichloroethane (1,1,1-TCA), 0.804; TCE, 0.458 (Tse et al. 1992); and chloroform (CF), 0.189 (Gosset 1987). After incubating the serum vials at $30^{\circ} \mathrm{C}$ and $250 \mathrm{rpm}$ for $60 \mathrm{~h}$, the $\mathrm{OD}_{600}$ was again measured to determine if growth was inhibited by any of the halogenated hydrocarbons.

Methane and halogenated hydrocarbon degradation assays

The cells were grown to mid-exponential phase $\left(\mathrm{OD}_{600}\right.$ of $\left.0.8-0.9\right)$ and then diluted to an $\mathrm{OD}_{600}$ of 0.3 with prewarmed fresh medium. To normalize rates of degradation to cell biomass, protein concentrations were measured using the BioRad protein assay kit with bovine serum albumin as a standard. The cells were digested at $90^{\circ} \mathrm{C}$ for $30 \mathrm{~min}$ in $5 \mathrm{M} \mathrm{NaOH}$. Serial dilutions were prepared to achieve final protein concentrations within the linear range of the assay. The amount of protein was determined by measuring the absorbance at $595 \mathrm{~nm}$ after the BioRad assay reagent had been added. In these experiments, the protein concentration of these cell suspensions varied between 0.092 and $0.098 \mathrm{mg} / \mathrm{ml}$. The initial rate of halogenated hydrocarbon degradation was analyzed using cells harvested as described earlier (Lontoh and Semrau 1998) and is briefly described here. After methane was removed from the growth flasks, 3-ml aliquots were aseptically transferred to $20-\mathrm{ml}$ serum vials. The vials were capped and sealed as described above. For each concentration of methane and halogenated hydrocarbon examined in these assays, triplicate samples were created with duplicate controls. Controls were made by adding $50 \mathrm{ml}$ of $5 \mathrm{M}$ $\mathrm{NaOH}$ except for $\mathrm{CF}$ and $\mathrm{BF}$, which were abiotically degraded at high $\mathrm{pH}$. The controls for $\mathrm{CF}$ and $\mathrm{BF}$ were made by adding $1 \%$ acetylene $(\mathrm{v} / \mathrm{v})$, an irreversible inhibitor of methane monooxygenase (Stirling and Dalton 1977; Prior and Dalton 1985).

After addition of substrate, vials were shaken at $250 \mathrm{rpm}$ at $30{ }^{\circ} \mathrm{C}$ again to prevent mass transfer effects from limiting measured rates of substrate degradation. Formate in the form of sodium formate was added at a concentration of $20 \mathrm{mM}$. The initial rates of degradation were determined by measuring the amount of halogenated hydrocarbon remaining using a Hewlett-Packard 5890 series II gas chromatograph with an automated head-space sampler, flame ionization detector (FID), and two DB-624 analytical columns (J\&W Scientific) The gas chromatograph was operated with a carrier gas flow rate of helium at a flow rate of $5.8 \mathrm{ml}$ $\mathrm{min}^{-1}$ and with injector, oven, and detector temperatures set at 160, 80 , and $250^{\circ} \mathrm{C}$, respectively. Initial rates of substrate degradation 
were determined over initial time frames depending on the substrate and extent of degradation. For those compounds readily degradable such as methane, DCM, DBM, and trans-DCE, a short time frame from $\mathrm{t}=0 \mathrm{~h}$ to $\mathrm{t}=1 \mathrm{~h}$ was used. The initial rate of TCE degradation was calculated using a 2 -h time period from $\mathrm{t}=0 \mathrm{~h}$ to $\mathrm{t}=2 \mathrm{~h}$ since this had previously been found to be appropriate (Lontoh and Semrau 1998). The initial degradation rates of more refractory halogenated hydrocarbons including VC, cis-DCE, and 1,1-DCE were measured over $5 \mathrm{~h}$. For BF, CF, and 1,1,1-TCA, the time frame to determine initial rates of degradation was extended to $10 \mathrm{~h}$ from $\mathrm{t}=0 \mathrm{~h}$ to $\mathrm{t}=10 \mathrm{~h}$ since these compounds were quite recalcitrant. The measured rates of degradation were normalized to the initial protein concentration, and the average initial degradation rate of triplicate samples is reported here along with the standard deviation. The kinetic parameters of apparent maximal degradation rate, $\mathrm{V}_{\max }\left[\mathrm{nmol} \mathrm{min} \mathrm{m}^{-1}(\mathrm{mg} \text { protein })^{-1}\right]$ and apparent affinity, $\mathrm{K}_{\mathrm{s}}(\mu \mathrm{M})$, were determined by applying nonlinear regression on the Michaelis-Menten formula using Kaelida Graph 3.0 for Macintosh.

Inhibition of whole-cell methane oxidation by halogenated hydrocarbons

To determine if pMMO activity was inhibited by the chosen brominated and chlorinated hydrocarbons, inhibition of pMMO activity was specifically measured. The cells were prepared as described above for determination of the Michaelis-Menten kinetics of halogenated hydrocarbon degradation. After aseptically transferring the diluted cells to 20 -ml serum vials, $100 \mu \mathrm{M}$ of the halogenated hydrocarbon was added with the exception of 1,1-DCE and cis-DCE. Since these substrates showed toxicity at concentrations greater than $10 \mu \mathrm{M}, 5 \mu \mathrm{M}$ was added to the vials. Triplicate samples were prepared for each halogenated hydrocarbon along with positive controls (no halogenated hydrocarbons) and negative controls (killed cells). The cells were incubated with the halogenated hydrocarbons for $5 \mathrm{~h}$ at $30^{\circ} \mathrm{C}$ while being shaken at $270 \mathrm{rpm}$. After $5 \mathrm{~h}$, the halogenated substrates were removed by purging the vials with air for $1 \mathrm{~min}$. Killed controls verified that this amount of time was sufficient for complete removal of the halogenated hydrocarbons as determined using head-space gaschromatographic analysis (data not shown). Methane (50 $\mu \mathrm{M}$; aqueous concentration) was then added, and the amount of methane consumed over $1 \mathrm{~h}$ was measured using the head-space analytical techniques described above.

Chemicals

All chemicals in the preparation of media were of reagent grade or better. Methane of the highest purity (> 99.99\%) was obtained from Matheson (Newark, N.J., USA). Chloroform [99.9\% gas chromatography (GC) grade], bromoform (99.5\% GC grade), 1,1,1-trichloroethane (99.9\% GC grade), 1,1-dichloroethylene (99\% GC grade), trans-dichloroethylene (98\% GC grade), cisdichloroethylene (97\% GC grade), dichloromethane (99\% GC grade), and dibromomethane (99.5\% GC grade) were purchased from Aldrich (Milwaukee, Wis., USA). Vinyl chloride (> 99.5\% GC grade) was purchased from Fluka (Ronkonkoma, N.Y., USA). Distilled-deionized water from a Corning Millipore D2 system was used for all experiments. All glassware was washed with detergent and then acid-washed in $2 \mathrm{M} \mathrm{HNO}_{3}$ overnight to remove trace metals, including copper. The acid was subsequently removed by repeated rinses with distilled-deionized water.

For compounds that are liquid at $25^{\circ} \mathrm{C}$ (i.e., $\mathrm{CF}, \mathrm{BF}, \mathrm{TCE}$, 1,1,1-TCA, 1,1-DCE, trans-DCE, cis-DCE, DCM, and DBM), stock saturated solutions were prepared by the method of Chang and Alvarez-Cohen (1996). Stock solutions were added to sample vials using Hamilton 1700 series gas-tight syringes, with care to exclude non-aqueous-phase liquids. For compounds that are gaseous at $25^{\circ} \mathrm{C}$ (i.e., $\mathrm{VC}$ and methane), samples were added to sample vials using Dynatech A-2 gas-tight syringes. Methanol was added as a $100 \%$ solution.

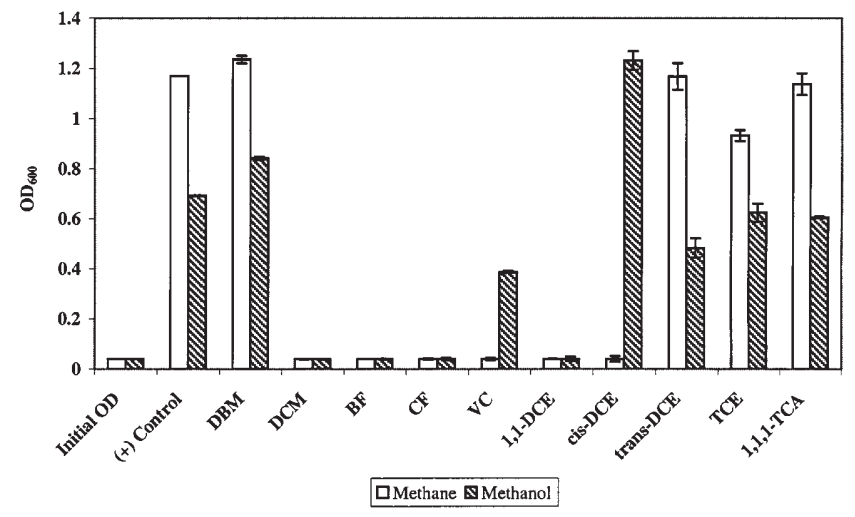

Fig. 1 Growth inhibition of Methylomicrobium album BG8 by chlorinated and brominated halogenated hydrocarbons. Cells were grown with either $550 \mu \mathrm{M}$ methane or $10 \mathrm{mM}$ methanol in the presence of $100 \mu \mathrm{M}$ of the halogenated hydrocarbon for $60 \mathrm{~h}$. Error bars indicate the range of duplicate samples (DBM dibromomethane, DCM dichloromethane, BF bromoform, $\mathrm{CF}$ chloroform, VC vinyl chloride, 1,1-DCE 1,1-dichloroethylene, cis-DCE cis-dichloroethylene, trans-DCE trans-dichloroethylene, TCE trichloroethylene, and 1,1,1-TCA 1,1,1-trichloroethane)

\section{Results}

Toxicity of halogenated compounds on the growth of M. album BG8

Since $M$. album BG8 can utilize both methanol and methane as carbon sources (Whittenbury et al. 1970; Bensted et al. 1998), examining growth of M. album BG8 in the presence of halogenated hydrocarbons and either methane or methanol will help determine if pMMO is inactivated over time in the presence of the halogenated hydrocarbons. As can be seen in Fig. 1, growth with methane as the sole carbon source was completely inhibited by $100 \mu \mathrm{M}$ solutions of six of the halogenated compounds tested (DCM, BF, CF, VC, 1,1-DCE, and cis-DCE). When methanol was used as the carbon source, inhibition of growth by some of these compounds (DCM, BF, CF, and 1,1-DCE) showed a similar pattern, indicating that the growth inhibition of $M$. album BG8 by these compounds was caused not solely by inactivation of pMMO, but also by the inactivation of other cell components. Interestingly, growth inhibition by $\mathrm{VC}$ and TCE in the presence of methanol was less than that in the presence of methane, suggesting that the toxicity associated with VC and TCE degradation selectively targets pMMO activity. Furthermore, cis-DCE appeared to stimulate the cell growth with methanol to the degree of growth with methane in the absence of $c i s$-DCE, although cis-DCE completely inhibited growth on methane. trans-DCE and 1,1,1-TCA inhibited growth with methanol (30 and $12 \%$, respectively), but did not substantially affect growth with methane.

\section{Kinetics of substrate degradation by $M$. album BG8}

Table 1 reports the values of apparent maximal uptake rate $\left(\mathrm{V}_{\mathrm{max}}\right)$ and apparent affinity $\left(\mathrm{K}_{\mathrm{s}}\right)$ using nonlinear re- 
Table 1 Michaelis-Menten kinetics for the degradation of methane and halogenated hydrocarbons by Methylomicrobium album BG8 expressing particulate methane monooxygenase. Values in parentheses represent the standard deviation of triplicate samples (DCM dichloromethane, DBM dibromomethane, CF chloroform, BF bromoform, VC vinyl chloride, trans-DCE transdichloroethylene, cis-DCE cis-dichloroethylene, 1,1-DCE 1,1dichloroethylene, TCE trichloroethylene, 1,1,1-TCA 1,1,1trichloroethane, and NM no measurable degradation)

\begin{tabular}{lllll}
\hline Substrate & $\begin{array}{l}\text { Apparent } \\
\mathrm{V}_{\max } \\
{\left[\mathrm{nmol} \cdot \mathrm{min}^{-1} \cdot\right.} \\
\left.(\mathrm{mg} \text { protein })^{-1}\right]\end{array}$ & $\begin{array}{l}\text { Apparent } \\
\mathrm{K}_{\mathrm{s}}\end{array}$ & $\begin{array}{l}\mathrm{V}_{\text {max }} / \mathrm{K}_{\mathrm{s}} \\
(\mathrm{ml} \cdot \mathrm{min} \cdot \\
\mathrm{mg} \text { protein })^{-1}\end{array}$ & $\begin{array}{l}\text { Concentra- } \\
\text { tion range } \\
(\mu \mathrm{M})\end{array}$ \\
\hline Methane & $453(13)$ & $19(2)$ & 25 & $0-80$ \\
DCM & $33(4)$ & $73(18)$ & 0.45 & $0-100$ \\
DBM & $45(3)$ & $171(29)$ & 0.26 & $0-400$ \\
CF & $\mathrm{NM}$ & $\mathrm{NM}$ & $\mathrm{NM}$ & $0-100$ \\
$\mathrm{BF}$ & $\mathrm{NM}$ & $\mathrm{NM}$ & $\mathrm{NM}$ & $0-100$ \\
VC & $7(0.5)$ & $30(7)$ & 0.23 & $0-100$ \\
trans-DCE & $43(6)$ & $60(19)$ & 0.72 & $0-100$ \\
cis-DCE & $0.12(0.01)$ & $0.8(0.2)$ & 0.15 & $0-10$ \\
$1,1-\mathrm{DCE}$ & $0.23(0.03)$ & $2.5(0.8)$ & 0.092 & $0-4$ \\
TCE & $4.3(0.1)$ & $59(3)$ & 0.072 & $0-120$ \\
$1,1,1-\mathrm{TCA}$ & $\mathrm{NM}$ & $\mathrm{NM}$ & $\mathrm{NM}$ & $0-100$ \\
\hline
\end{tabular}

gression analysis to fit the Michaelis-Menten equation to the measured initial rates of degradation for each substrate. Most of the compounds tested were degraded by M. album BG8, with the exception of $\mathrm{BF}, \mathrm{CF}$, and 1,1,1TCA. DCM, DBM, trans-DCE, TCE, and VC were all readily degraded in the presence of formate at a rate of approximately $1-10 \%$ of the $\mathrm{V}_{\max }$ of methane consumption. 1,1-DCE and cis-DCE were also degraded, but the maximal transformation rates of these compounds was less than $0.5 \%$ of the maximal rate of methane consumption. Also shown in Table 1, the whole-cell affinity for DCM, DBM, TCE, trans-DCE, and VC was much less than that for methane, with affinity typically decreasing as the size of halogen substituents increased. For example, DBM and DCM had relatively similar $\mathrm{V}_{\max }$ values, but the $\mathrm{K}_{\mathrm{s}}$ value for DBM was more than twice that for DCM. 1,1-DCE and $c i$-DCE had lower $\mathrm{K}_{\mathrm{s}}$ values than methane, however, suggesting that the apparent affinity of M. album BG8 for these compounds was greater than that for methane.

All halogenated hydrocarbons that were degraded, however, had pseudo-first-order rate constants $\left(\mathrm{V}_{\max } / \mathrm{K}_{\mathrm{s}}\right)$ at least 40 -fold less than those for methane (Table 1). Such a large difference indicates that $M$. album BG8 expressing pMMO is highly selective. The remaining compounds tested (CF, BF, and 1,1,1-TCA) were not measurably degraded by $M$. album BG8 and are apparently very poor substrates. To determine if pMMO was responsible for the degradation of those compounds readily degraded (DCM, DBM, trans-DCE, cis-DCE, 1,1-DCE, TCE, and VC), acetylene, a potent inhibitor of MMO (Prior and Dalton 1985), was added at $1 \%(\mathrm{v} / \mathrm{v})$ to cell suspensions. In the presence of acetylene, no degradation was observed for any of the compounds for over $5 \mathrm{~h}$. Therefore, pMMO was solely responsible for halogenated hydrocarbon degradation (data not shown).

Table 1 also reports the concentration range used to determine the apparent $\mathrm{V}_{\max }$ and $\mathrm{K}_{\mathrm{s}}$ values for the degradation of the halogenated hydrocarbons and methane. Of the compounds that were degraded, standard hyperbolic Michaelis-Menten kinetics were observed when aqueous concentrations were increased up to $100 \mu \mathrm{M}$ (120 and 400 $\mu \mathrm{M}$ for TCE and DBM, respectively). The notable exceptions, however, are 1,1-DCE and cis-DCE. For these two substrates, the Michaelis-Menten kinetic parameters were determined using concentration ranges of $0-4 \mu \mathrm{M}$ and $0-10 \mu \mathrm{M}$, respectively. These substrates apparently are toxic at relatively low concentrations $(<100 \mu \mathrm{M})$. The degradation of $\mathrm{CF}, \mathrm{BF}$, and 1,1,1-TCA was also monitored, but since no substrate disappearance was observed at concentrations of up to $100 \mu \mathrm{M}$, it was assumed that these compounds were not biodegradable by $M$. album BG8.

Inactivation of methane oxidation by halogenated hydrocarbons

The effect of these halogenated hydrocarbons on pMMO activity is reported in Fig. 2 and Table 2. 1,1-DCE and cisDCE showed almost complete inhibition of pMMO activity after incubating $M$. album BG8 for $5 \mathrm{~h}$ in the presence of $5 \mu \mathrm{M}$ of these chlorinated ethylenes. CF also completely inhibited pMMO activity, and VC and TCE reduced pMMO activity by approximately $85 \%$, but at much higher initial concentrations of $100 \mu \mathrm{M}$. Of the remaining compounds, $\mathrm{BF}$ inhibited methane oxidation by approximately 50\%, while trans-DCE, DCM, DBM, and $1,1,1-$ TCA reduced pMMO activity by $20-30 \%$. These

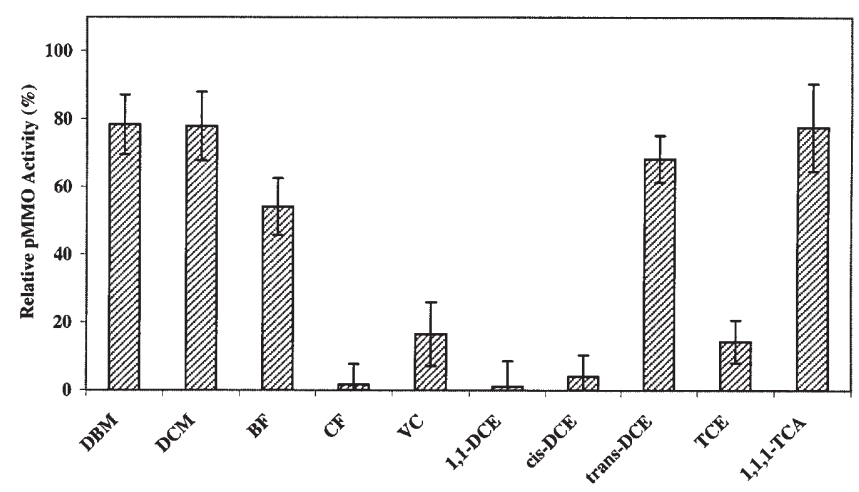

Fig. 2 Inhibition of particulate methane monooxygenase (pMMO) activity in whole cells of Methylomicrobium album BG8 after exposure to chlorinated and brominated hydrocarbons for $5 \mathrm{~h}$. The concentration of the halogenated hydrocarbon was $100 \mu \mathrm{M}$ with the exception of 1,1-DCE and cis-DCE, which were added at a concentration of $5 \mu \mathrm{M}$. Error bars indicate the standard deviation of triplicate samples (DBM dibromomethane, DCM dichloromethane, $\mathrm{BF}$ bromoform, $\mathrm{CF}$ chloroform, $\mathrm{VC}$ vinyl chloride, 1,1DCE 1,1-dichloroethylene, cis-DCE cis-dichloroethylene, transDCE trans-dichloroethylene, TCE trichloroethylene, and 1,1,1TCA 1,1,1-trichloroethane) 
Table 2 Effect of halogenated hydrocarbons on methanotrophic and ammonia-oxidizer activity. Compounds are classified as either I not biodegradable with little inactivation, II biodegradable with little inactivation, III biodegradable with substantial inactivation, or IV not biodegradable but with substantial inactivation. Values in parentheses represent the standard deviation of triplicate sam- ples (1,1,1-TCA 1,1,1-trichloroethane, DBM dibromomethane, DCM dichloromethane, VC vinyl chloride, 1,1-DCE 1,1dichloroethylene, trans-DCE trans-dichloroethylene, cis-DCE cisdichloroethylene, TCE trichloroethylene, BF bromoform, CF chloroform, pMMO particulate methane monooxygenase, and ND not determined)

\begin{tabular}{|c|c|c|c|c|c|c|}
\hline \multirow[t]{2}{*}{$\begin{array}{l}\text { Halogenated } \\
\text { hydrocarbon }\end{array}$} & \multicolumn{3}{|c|}{$\begin{array}{l}\text { Methylomicrobium album BG8 } \\
\text { (This study) }\end{array}$} & \multicolumn{3}{|c|}{$\begin{array}{l}\text { Nitrosomonas europaea } \\
\text { (Rasche et al. 1991) }\end{array}$} \\
\hline & $\begin{array}{l}\text { Amount added } \\
(\mu \mathrm{M})\end{array}$ & $\begin{array}{l}\text { pMMO activity } \\
(\%)\end{array}$ & $\begin{array}{l}\text { Compound } \\
\text { classification }\end{array}$ & $\begin{array}{l}\text { Amount added } \\
(\mu \mathrm{M})^{\mathrm{a}}\end{array}$ & $\begin{array}{l}\mathrm{O}_{2} \text { uptake } \\
(\%)\end{array}$ & $\begin{array}{l}\text { Compound } \\
\text { classification }\end{array}$ \\
\hline $1,1,1-\mathrm{TCA}$ & 100 & 78 (13) & I & 600 & 53 & III \\
\hline DBM & 100 & $78 \quad$ (9) & II & ND & ND & ND \\
\hline DCM & 100 & 78 (10) & II & 1,900 & 60 & III \\
\hline 1,1-DCE & 5 & 1 (7) & III & 7.5 & 3 & III \\
\hline trans-DCE & 100 & (7) & III & 121 & 50 & III \\
\hline cis-DCE & 5 & (6) & III & 125 & 4 & III \\
\hline TCE & 100 & (6) & III & 109 & 3 & III \\
\hline $\mathrm{BF}$ & 100 & $54 \quad(8)$ & IV & ND & ND & ND \\
\hline $\mathrm{CF}$ & 100 & 2 (6) & IV & 740 & 1 & III \\
\hline
\end{tabular}

${ }^{a}$ Converted from reported units of $\mu \mathrm{mol}$ using the Henry constants reported in Materials and methods

activity assays were performed after the halogenated hydrocarbons had been removed to minimize the possibility of the substrate(s) themselves causing a reduction in pMMO activity. It is possible, however, that some substrates remained strongly bound to the $\mathrm{pMMO}$, causing an apparent decrease in activity.

The results of the effect of these compounds on growth, pMMO activity, and the measured MichaelisMenten parameters of apparent $\mathrm{V}_{\max }$ and $\mathrm{K}_{\mathrm{s}}$ suggest that these compounds can be divided into four groups similar to the ones proposed by Rasche et al. (1991). 1,1,1-TCA was found neither to be toxic nor to be degraded by M. album $\mathrm{BG} 8$, and could be considered as a single category of halogenated substrates. DCM and DBM also had little effect on either growth or pMMO activity, but were readily degraded and thus were considered to be a second group of substrates. A third group consisting of the chlorinated ethylenes (trans-DCE, VC, 1,1-DCE, cis-DCE, and TCE) were also substrates of the pMMO, but their oxidation significantly affected both growth and pMMO activity. Finally, we discovered a fourth group of halogenated hydrocarbons $(\mathrm{CF}$ and $\mathrm{BF})$ that were not measurably oxidized by pMMO-expressing cells but that had significant toxicity to growth on both methane and methanol and also substantially reduced whole-cell pMMO activity.

\section{Discussion}

The growth of M. album BG8 with methane as a sole carbon source was completely inhibited by many of halogenated hydrocarbons tested. i.e., DCM, CF, BF, cis-DCE, $\mathrm{VC}$, and 1,1-DCE. trans-DCE was not found to inhibit growth on methane. These results are in agreement with the findings of growth inhibition of a mixed methan- otrophic culture with methane as a growth substrate in the presence of DCM, CF, trans-DCE, cis-DCE, and TCE at concentrations varying from 30 to $80 \mu \mathrm{M}$ (Janssen et al. 1988). VC was not tested in that study. Interestingly, 1,1,1-TCA was also found to inhibit growth of this mixed culture on methane, but 1,1,1-TCA had little effect on the growth of M. album BG8 on methane. It is possible that in the mixed culture, sMMO was being expressed. This form of the MMO has been shown to degrade 1,1,1-TCA, while the pMMO does not (Oldenhuis et al. 1989). Since M. album BG8 can only express pMMO, toxicity of the products of 1,1,1-TCA oxidation was minimized in the experiments presented here.

The inhibition of growth on methane could have been due to competition between the halogenated hydrocarbon and methane for binding sites in $\mathrm{PMMO}$, product toxicity, or both. To determine if competition for pMMO binding sites was responsible for the measured growth inhibition on methane, M. album BG8 was also grown on methanol in the presence of these halogenated hydrocarbons. As shown in Fig. 1, growth of M. album BG8 on methanol was clearly affected by many these compounds. DCM and 1,1-DCE completely inhibited growth on methanol, while VC and TCE reduced the extent of growth over $60 \mathrm{~h}$ by 44 and $10 \%$, respectively. Furthermore, DCM, 1,1-DCE, VC, and TCE were degraded and followed hyperbolic kinetics, indicating that product toxicity and not substrate toxicity was responsible for growth inhibition. Such a conclusion is supported by the finding of Dolan and McCarty (1995) that the transformation product of 1,1-DCE is highly toxic to a mixed methanotrophic culture. This finding is supported by assays of reduced whole-cell pMMO activity after incubation of $M$. album BG8 with these compounds for $5 \mathrm{~h}$ and subsequent removal (Table 2). Since growth on both methanol and methane was affected, apparently 
the transformation products can inhibit other enzymatic processes as well as the pMMO. The products of $\mathrm{VC}$ and TCE oxidation, however, appear to predominantly inhibit pMMO activity since growth on methane was more strongly affected.

Of the other compounds, $\mathrm{CF}$ and $\mathrm{BF}$ also completely inhibited growth on both methane and methanol and also substantially inhibited pMMO activity. These compounds, however, were not measurably degraded by $M$. album BG8. Thus, it is likely that these compounds themselves were toxic to the cells. DBM had no affect on growth with methane or methanol, suggesting that neither DBM nor its oxidative products were toxic to $M$. album BG8. 1,1,1TCA reduced growth on methanol by $12 \%$, but had no affect on growth on methane. It is unclear why growth on methanol was affected by 1,1,1-TCA since 1,1,1-TCA was not seen to be degraded. trans-DCE was not found to inhibit growth on methane after $60 \mathrm{~h}$, but the products of oxidation did inhibit pMMO activity as shown in Table 2, and also growth on methanol was reduced by approximately $30 \%$ in the presence of trans-DCE. It is possible that the products of trans-DCE oxidation are inhibitory, but not as significantly as the products of TCE, VC, and 1,1-DCE oxidation. Finally, cis-DCE was toxic to cells grown on methane, but had little effect on cells grown with methanol. This suggests that cis-DCE or its products selectively inhibit pMMO activity. This result is supported by the finding that after incubating $M$. album BG8 for $5 \mathrm{~h}$ with $5 \mu \mathrm{M}$ cis-DCE, no methane consumption could be measured, indicating that pMMO was inactivated.

Not surprisingly, the apparent $V_{\max }$ values found for halogenated hydrocarbons degraded readily by pMMO in M. album BG8 in this study were smaller than the $\mathrm{V}_{\max }$ measured for methane (Table 1). Comparison of the $\mathrm{K}_{\mathrm{s}}$ values to the value for methane, however, reveals a different pattern. The apparent $\mathrm{K}_{\mathrm{s}}$ values of all compounds with the exception of 1,1-DCE and cis-DCE were greater than the apparent $\mathrm{K}_{\mathrm{s}}$ value for methane by $\mathrm{M}$. album BG8. These two compounds apparently are bound much better to $\mathrm{pMMO}$ than the primary substrate, methane. Although this result is unusual, it is not unprecedented. The ammonia monooxygenase (AMO), an enzyme structurally and genetically similar to $\mathrm{pMMO}$, also was found to bind some chlorinated hydrocarbons greater than its primary substrate, ammonia. Using whole cells of Nitrosomonas europaea, Ely et al. (1997) have discovered that the relative affinity of whole cells expressing AMO is greater for both 1,1-DCE and TCE than it is for ammonia. Furthermore, kinetic analysis of whole-cell degradation of chlorinated hydrocarbons by $M$. trichosporium OB3b expressing sMMO indicates that whole-cell affinity for both 1,1DCE and cis-DCE, and CF and DCM is better than that for methane (Oldenhuis et al. 1991). Although some chlorinated hydrocarbons apparently bind more strongly to pMMO in whole cells, the pseudo-first-order rate constant $\left(\mathrm{V}_{\max } / \mathrm{K}_{\mathrm{s}}\right)$ for all of the degraded compounds was much less than that measured for methane (Table 1), indicating that in whole cells the preferred substrate is methane. Furthermore, the lower pseudo-first-order rate constant and larger $\mathrm{K}_{\mathrm{s}}$ for DBM degradation relative to that of DCM suggests that the larger size of bromine interferes with the effective transformation of DBM.

Although the authors are aware of no previous studies that have measured the Michaelis-Menten kinetic parameters of $\mathrm{V}_{\max }$ and $\mathrm{K}_{\mathrm{s}}$ for many of the chlorinated and brominated hydrocarbons examined here, one earlier study has measured the pseudo-first-order rate constants of whole-cell degradation of chlorinated methanes and ethanes by $M$. trichosporium OB3b expressing pMMO (Van Hylckama Vleig et al. 1996). As shown in Table 3, values of pseudo-first-order constants for halogenated compounds by $\mathrm{pMMO}$ in $M$. album BG8 found here were lower than those reported in M. trichosporium OB3b ex-
Table 3 Comparison of pseudo-first-rate constants of halogenated hydrocarbon degradation by methanotrophs known to be expressing soluble methane monooxygenase (sMMO) or particulate methane monooxygenase (pMMO) (DCM dichloromethane, DBM dibromomethane, CF chloroform, BF bromoform, VC vinyl chlo-

\begin{tabular}{|c|c|c|c|}
\hline Compound & $\begin{array}{l}\text { Methylosinus trichosporium } \\
\text { OB3b expressing sMMO } \\
\text { (Van Hylckama Vleig et al. 1996) } \\
{\left[\mathrm{ml} \mathrm{min} \text { mi }^{-1}(\mathrm{mg} \text { protein })^{-1}\right]}\end{array}$ & $\begin{array}{l}\text { Methylosinus trichosporium } \\
\text { OB3b expressing pMMO } \\
\text { (Van Hylckama Vleig et al. 1996) } \\
{\left[\mathrm{ml} \mathrm{min} \text { mi }^{-1}(\mathrm{mg} \text { protein })^{-1}\right]^{\mathrm{a}}}\end{array}$ & 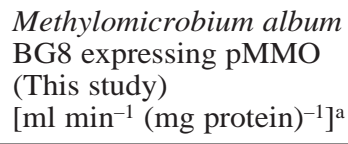 \\
\hline DCM & 16 & 1.4 & 0.45 \\
\hline DBM & ND & ND & 0.26 \\
\hline $\mathrm{CF}$ & 2.6 & 0.06 & NM \\
\hline $\mathrm{BF}$ & ND & ND & NM \\
\hline VC & 15.2 & 3.8 & 0.23 \\
\hline trans-DCE & 6.6 & 1.8 & 0.72 \\
\hline cis-DCE & 9.8 & 0.12 & 0.15 \\
\hline 1,1-DCE & 6.4 & $<0.06$ & 0.092 \\
\hline TCE & 6.2 & $<0.06$ & 0.072 \\
\hline 1,1,1-TCA & ND & ND & NM \\
\hline
\end{tabular}

ride, trans-DCE trans-dichloroethylene, cis-DCE cis-dichloroethylene, 1,1-DCE 1,1-dichloroethylene, TCE trichloroethylene, 1,1,1-TCA 1,1,1-trichloroethane, NM no measurable degradation, and ND not determined)

${ }^{a}$ Converted from reported units of $\mathrm{ml} \mathrm{min}^{-1}$ (mg cells) $)^{-1}$ assuming cell mass is $50 \%$ protein 
pressing pMMO. It is unknown why the rates for $M$. trichosporium OB3b were so much greater, in some cases over an order of magnitude greater, but for the commonly tested substrates, both strains showed faster rates of transformation for DCM, VC, and trans-DCE. Regardless of the difference in rates found between methanotrophs expressing $\mathrm{pMMO}$, it is clear from the data presented here and elsewhere that pMMO rates of degradation of halogenated hydrocarbons are slower than the rate in cells expressing sMMO. The affinity of pMMO for many of these compounds (particularly the chlorinated ethylenes), however, is typically much better than that measured for methanotrophs expressing sMMO (Van Hylckama Vleig et al. 1996). This supports the use of cells expressing pMMO in certain situations where concentrations may be low although the overall rate of degradation will be low. Based on the kinetics of chlorinated ethylene degradation at a field demonstration site at Moffett Naval Air Station (Mountain View, CA, USA), it has now been suggested that pMMO was actually being expressed by the in situ methanotrophic community (McCarty 1997). This indicates that whole-cell pMMO-mediated degradation can be stimulated with the provision of limiting growth substrates.

The results of the effects of these compounds on growth, on pMMO activity, and on the measured MichaelisMenten parameters of apparent $\mathrm{V}_{\max }$ and $\mathrm{K}_{\mathrm{s}}$ indicate that the halogenated hydrocarbons can be divided into four groups: (I) not biodegradable with little inactivation, (II) biodegradable with little inactivation, (III) biodegradable with substantial inactivation, and (IV) not biodegradable but with substantial inactivation of cell activity. This characterization was first proposed by Rasche et al. (1991) for the AMO of $N$. europaea. Since AMO and pMMO are quite similar, it is interesting to compare our findings to those of N. europaea, as shown in Table 2. The units reported in the AMO study have been converted from $\mu \mathrm{mol}$ to $\mu \mathrm{M}$ to facilitate comparison using the Henry's constants reported earlier in Materials and methods. All five of the chlorinated ethenes assayed in M. album BG8 and $N$. europaea were classified into the same group (III). Of the two other common compounds tested, DCM was found to inhibit whole-cell pMMO activity less significantly than whole-cell AMO activity (22 vs $40 \%$, respectively) and, thus, was classified as a group II compound while it is considered a group III compound for N. europaea. This may partly be due to the fact that in the experiments performed here, $M$. album BG8 was incubated for $5 \mathrm{~h}$ in the presence of $100 \mu \mathrm{M}$ DCM as opposed to $N$. europaea (exposed to $1900 \mu \mathrm{M}$ for $1 \mathrm{~h}$ ). 1,1,1-TCA was considered to be a group I compound for M. album BG8 since it was not degraded and showed little inactivation. In $N$. europaea, however, it was classified as a group III compound since it was degraded and significantly affected whole-cell AMO activity. AMO is apparently able to oxidize 1,1,1-TCA while pMMO does not, and the products of oxidation are toxic. Finally, we discovered a fourth group of halogenated hydrocarbons, $\mathrm{CF}$ and $\mathrm{BF}$, that were not measurably oxidized by pMMO-expressing cells but that prevented any growth on both methane and methanol and also significantly reduced whole-cell pMMO activity. This suggests that these compounds themselves are toxic to the cells and that such toxicity is not specific to $\mathrm{pMMO}$, but rather is more general and may affect multiple enzymatic processes. Product toxicity, however, cannot be excluded since some small amount of substrate may have been oxidized into toxic product(s). Such uncertainty is apparent when one considers that previous research is unclear on the ability of cells expressing pMMO to degrade CF. One early study has indicated that CF can be degraded (Oldenhuis et al. 1989), but a more recent one has reported that the rate is less than the detection limit (Van Hylckama Vleig et al. 1996). It has also been shown that CF is degraded by $N$. europaea and is toxic to these cells, with toxicity not limited to inhibition of AMO (Ely et al. 1997). It is possible that cells expressing pMMO can degrade trihalomethanes with the formation of nonspecific inhibitory products, but the appropriate conditions are uncertain and further research should be performed to determine if and when methanotrophs expressing $\mathrm{pMMO}$ can degrade $\mathrm{CF}$ and $\mathrm{BF}$.

Acknowledgements Research support from the National Science Foundation to J. D. Semrau (grant no. MCB-9708557) is gratefully acknowledged.

\section{References}

Arp DJ (1995) Understanding the diversity of trichloroethylene cooxidations. Curr Opin Biotechnol 6:352-358

Benstead J, King GM, Williams HG (1998) Methanol promotes atmospheric methane oxidation by methanotrophic cultures and soils. Appl Environ Microbiol 64:1091-1098

Bouwer EJ, McCarty PL (1983) Transformation of 1- and 2-carbon halogenated aliphatic compounds under methanogenic condition. Appl Environ Microbiol 45:1286-1294

Cardy DLN, Laidler V, Salmond GPC, Murrell JC (1991) Molecular analysis of the methane monooxygenase (MMO) gene cluster of Methylosinus trichosporium OB3b. J Gen Microbiol $5: 335-342$

Chang HL, Alvarez-Cohen L (1996) Biodegradation of individual and multiple chlorinated aliphatic hydrocarbons by methaneoxidizing cultures. Appl Environ Microbiol 62:3371-3377

DiStefano TD, Gossett JM, Zinder SH (1991) Reductive dechlorination of high concentrations of tetrachloroethene to ethene by an anaerobic enrichment culture in the absence of methanogenesis. Appl Environ Microbiol 57:2287-2292

Dolan ME, McCarty PL (1995) Methanotrophic chloroethene transformation capacities and 1,1-dichloroethene transformation product toxicities. Environ Sci Technol 29: 2741-2747

Ely RL, Williamson KJ, Hyman MR, Arp DJ (1997) Cometabolism of chlorinated solvents by nitrifying bacteria: kinetics, substrate interactions, toxicity effects, and bacterial response. Biotech Bioeng 54:520-534

Ensley BD (1991) Biochemical diversity of trichloroethylene metabolism. Annu Rev Microbiol 45:283-299

Fox BG, Borneman JG, Wackett LP, Lipscomb JD (1990) Haloalkene oxidation by soluble methane monooxygenase from Methylosinus trichosporium OB3b: mechanistic and environmental application. Biochemistry 29:6419-6427

Gosset JM (1987) Measurement of Henry's law constants for C1 and $\mathrm{C} 2$ chlorinated hydrocarbon. Environ Sci Technol 21: 202-208

Hanson RS, Hanson TE (1996) Methanotrophic bacteria. Microbiol Rev 60:439-471 
Janssen DB, Grobben G, Hoekstra R, Oldenhuis R, Witholt B (1988) Degradation of trans-1, 2-dichloroethene by mixed cultures of methanotrophic bacteria. Appl Environ Biotechnol 29:392-399

Lontoh S, Semrau JD (1998) Methane and trichloroethylene degradation by Methylosinus trichosporium OB3b expressing particulate methane monooxygenase. Appl Environ Microbiol 64: 1106-1114

McCarty PL (1997) Aerobic cometabolism of chlorinated aliphatic hydrocarbons. In: Ward CH, Cherry JA, Scalf MR (eds) Subsurface restoration. Ann Arbor Press, Chelsa, MI, pp 373-395

McTavish H, Fuchs JA, Hooper AB (1993) Sequence of the gene coding for ammonia monooxygenase in Nitrosomonas europaea. J Bacteriol 175:2436-2444

Morel FM, Hering JG (1991) Principles and applications of aquatic chemistry. Wiley, New York

Oldenhuis R, Vink RLJM, Janssen DB, Witholt B (1989) Degradation of chlorinated aliphatic hydrocarbon by Methylosinus trichosporium $\mathrm{OB} 3 \mathrm{~b}$ expressing soluble methane monooxygenase. Appl Environ Microbiol 55:2819-2826

Oldenhuis R, Oedzes JY, Van der Waarde JJ, Janssen DB (1991) Kinetics of chlorinated hydrocarbon degradation by Methylosinus trichosporium OB3b and toxicity of trichloroethylene. Appl Environ Microbiol 57:7-14

Prior SD, Dalton H (1985) Acetylene as a suicide substrate and active site probe for methane monooxygenase from Methylococcus capsulatus (Bath). FEMS Microbiol Lett 29:105-109

Rasche ME, Hyman MR, Arp DJ (1991) Factors limiting aliphatic chlorocarbon degradation by Nitrosomonas europaea: cometabolic inactivation of ammonia monooxygenase and substrate specificity. Appl Environ Microbiol 57:2986-2994

Rosenzweig AC, Frederick CA, Lippard SJ, Nordlund P (1993) Crystal structure of a bacterial non-haem iron hydroxylase that catalyses the biological oxidation of methane. Nature 366:53743
Semprini L (1997) In situ transformation of halogenated aliphatic compounds under anaerobic conditions. In: Ward $\mathrm{CH}$, Cherry JA, Scalf MR (eds) Subsurface restoration. Ann Arbor Press, Chelsa, Mich., pp 429-450

Semrau JD, et al (1995) Particulate methane monooxygenase genes in methanotrophs. J Bacteriol 177:3071-3079

Stirling DI, Dalton H (1977) Effect of metal-binding agents and other compounds on methane oxidation by two strains of Methylococcus capsulatus. Arch Microbiol 114:71-76

Tse G, Orbey H, Sandler SI (1992) Infinite dilution activity coefficients and Henry's law coefficients of some priority water pollutants determined by a relative gas chromatographic method. Environ Sci Technol 26:2017-2022

Van Hylckama Vlieg JET, De Koning W, Janssen DB (1996) Transformation kinetics of chlorinated ethenes by Methylosinus trichosporium $\mathrm{OB} 3 \mathrm{~b}$ and detection of unstable epoxides by on-line gas chromatography. Appl Environ Microbiol 62: 3304-3312

Vogel TM, McCarty PL (1985) Biotransformation of tetrachloroethylene, dichloroethylene, vinyl chloride, and carbon dioxide under methanogenic conditions. Appl Environ Microbiol 49:1080-1083

Wackett LP (1995) Bacterial co-metabolism of halogenated organic compounds. In: Young YL, Cerniglia CE (ed) Microbial transformation and degradation of toxic organic chemicals. Wiley-Liss, New York, pp 217-241

Westrick JJ, Mello JW, Thomas RF (1984) The groundwater supply survey. J Am Water Works Assoc 76:52-59

Whittenbury RK, Philips KD, Wilkinson JF (1970) Enrichment, isolation and some properties of methane-utilizing bacteria. J Gen Microbiol 61:205-218 